References

Bridgwater, D., Watson, J. \& Windley, B. F. 1973: The Archaean Craton of the North Atlantic region. Phil. Trans. R. Soc. Lond. A, 273, 493-512.

McGregor, V. R. 1973: The early Precambrian gneisses of the Godthåb district, West Greenland. Phil. Trans. R. Soc. Lond. A, 273, 343-358.

Noe-Nygaard, A. \& Ramberg, H. 1961: Geological reconnaissance map of the country between latitudes $69^{\circ} \mathrm{N}$ and $63^{\circ} 45 \mathrm{~N}$, West Greenland. Map Grønlands geol. Unders. 1 (also Meddr Grønland 123,5) 2 sheets, 9 pp.

Department of Geology, Makerere University, P.O. Box 7062, Kampala, Uganda.

\title{
FIELD WORK ON THE VERY EARLY PRECAMBRIAN ROCKS OF THE ISUA AREA, SOUTHERN WEST GREENLAND
}

\section{David Bridgwater and V. R. McGregor}

During the regional mapping programme in the Godthåbsfjord region (see Bridgwater \& McGregor, this report p. 39) D. B. and V. R. M. spent 14 days in the Isua area near the margin of the Inland Ice, approximately $150 \mathrm{~km}$ north-east of Godthåb, in order to examine the Isua supracrustal suite and to determine its relation to the surrounding gneisses and to the geology of Godthåbsfjord.

The area had previously been mapped and reported on by Kryolitselskabet $\emptyset$ resund A/S. The general distribution of rock types and structure described by Kryolitselskabet Øresund geologists was confirmed during the summer, although there are considerable differences in final interpretation. Age determinations made on Isua gneisses by the Oxford isotope geology laboratory have given a $\mathrm{Rb} / \mathrm{Sr}$ whole rock date of $3700 \pm 140 \mathrm{~m} . y$. , which is identical, within analytical error, with $\mathrm{Rb} / \mathrm{Sr}$ whole rock isochron dates from the type Amitsoq gneisses near Godthåb (Moorbath et al., 1972). Ironstones from the supracrustals have given a $\mathrm{Pb} / \mathrm{Pb}$ whole rock isochron age of $3760 \pm 70 \mathrm{y} . \mathrm{m}$., which is thought to be the result of a metamorphic event that was accompanied by severe uranium depletion (Moorbath et al., 1973). At the time of writing the Isua rocks are thus the oldest known supracrustal succession on Earth and as such are of considerable interest because of the insight they may give about early conditions in the Earth's crust and atmosphere.

4 Rapport 65 


\section{General setting}

The Isua supracrustal rocks form a belt of low- to medium-grade greenstones and metasediments enclosed in gneisses. They have been folded into a semicircular arc $25 \mathrm{~km}$ in diameter around an asymmetrical domal structure, the core of which is composed of gneisses. To the north the supracrustal rocks are faulted out; to the east they disappear under the Inland Ice. The supracrustal belt reaches a maximum width of approximately $3-4 \mathrm{~km}$ along the margin of the Inland Ice, but thins to less than $1 \mathrm{~km}$ where it crosses the lake called 'Imarssuak'. Contacts with the enclosing gneisses are sharp and near vertical. Planar structures within the belt dip steeply and follow the trend of the belt itself. The supracrustal rocks have a strong, steeply-plunging, linear fabric element which is most obvious in the form of pencil lineations and elongated conglomerate pebbles.

The supracrustal rocks and the gneisses both within and outside the dome are cut by two major generations of metadolerite dykes, some of which reach nearly over $25 \mathrm{~m}$ in width. Individual dykes can be traced for $10 \mathrm{~km}$ or more. A small proportion of the dykes contain recrystallised plagioclase megacrysts, a feature which is characteristic of the type Ameralik dykes in the Godthåbsfjord region. The dykes cutting the gneisses within the dome are little deformed and commonly preserve much original igneous texture. Those which are sub-parallel to the strike of the gneisses are arched around the domal structure and some of them were intruded as a series of elongate pods. These may have been injected under conditions of regional stress. Dykes that trend at a high angle to the regional structure are practically undeformed and regular. A number of dykes pass from the gneisses in the core of the dome into the supracrustal belt where some are quite strongly deformed and display small-folded apophyses.

South of the supracrustal belt the basic dykes become progressively more deformed and recrystallised, and on the shores of 'Imarssuak' some $3 \mathrm{~km}$ south of the supracrustal belt they are completely recrystallised to amphibolites, slightly boudinaged, and cut by thick pegmatites. At this stage they are identical with the least deformed Ameralik dykes in the area south-east of Godthåb. Although the geology has not yet been traced out between this point and Ujaragssuit, $40 \mathrm{~km}$ to the south, at the head of Godthåbsfjord, where typical highly broken-up Ameralik dykes have been recognised, there seems little doubt that the basic dykes in the Isua area will prove to be equivalent to the type Ameralik dykes.

The supracrustal belt is cut off to the west by a major fault that marks the edge of a belt with a strong NNW-SSE trending fabric that is prominent on the aerial photographs. We suggest that this is the boundary of a tectonic enclave that escaped the heavy post-Ameralik dyke deformation seen to the south and west in the Godthåbsfjord region. The Isua enclave is at least $30 \mathrm{~km}$ wide and must extend eastwards under the Inland Ice. It remained stable during the later tectonic, magmatic and metamorphic events that affected the remainder of the West Greenland Archaean. 


\section{Stratigraphy of the supracrustal belt}

The supracrustal rocks, particularly in the east, show a rough bilateral symmetry with a mixed group of amphibolites and other finely layered dark rocks and some thin siliceous horizons forming the border group on either side. Major, fairly homogeneous greenschists (in places with 'garbenschiefer' texture) occur both in the border group and sporadically nearer the centre of the belt. They may be derived from basic sills emplaced within the original succession. The dominantly basic mixed-border group grades into a succession of metasediments with thin quartz-magnetite horizons, pelitic horizons, calcareous units and some amphibolites. Thin horizons of talc schist occur within the successions.

Approximately along the junction between the mixed basic border group and the metasediments the belt contains elongate masses of ultrabasic rock, some of which are over a kilometre long and 50 to $100 \mathrm{~m}$ thick. The majority consist of talc-actinolite-chlorite schists, however some consist almost entirely of magnesiumrich olivine grains set in a serpentine groundmass. It seems possible that at least some of the ultrabasic rocks may have been original submarine lavas. The ultrabasic rocks are associated with a bedded, very dark green amphibolitic rock sometimes up to $100 \mathrm{~m}$ or more across the strike.

The sedimentary rocks found near to the centre of the belt contain a high proportion of carbonate. Well-layered quartzo-feldspathic rocks with a high carbonate content in the matrix are found adjacent to almost pure brown-weathering carbonate rocks interlayered with strings, lenses and layers of diopside and actinolitic amphibole. The easternmost outcrops of the central part of the belt contain a major banded ironstone unit estimated to contain at least two thousand million tons of ore (Keto, 1969). The solid outcrops of this body consist of alternating layers of magnetite and quartz with some iron amphibole. However numerous boulders of float suggest the presence of a major haematite-bearing body below the Inland Ice. The ironstones pass gradationally into thick carbonate-rich quartzites with progressively fewer magnetite layers.

The central sedimentary units within the belt outcropping close to the shore of lake 'Imarssuak' consist of a well-defined conglomeratic unit with cobs and boulders ranging from a few centimetres to 2 metres in diameter, set in a fine-grained, carbonate-bearing matrix. This easily identifiable unit can be traced for at least $14 \mathrm{~km}$ along strike. Over the major part of the outcrop the fragments within the unit are so deformed and sheared out that they only show up as light elongate discs within a slightly darker buff-coloured matrix. A relatively little deformed outcrop of this unit occurs on the eastern shore of 'Imarssuak'. At this locality the boulders can be seen to consist mainly of pale, fine-grained, muscovite-rich, quartzo-feldspathic rocks. Some of the boulders appear to have been cut by pegmatitic veins before being included in the present sedimentary host. Other boulders contain blebs of quartz and could be derived from acid volcanic or hyperbyssal parents. Preliminary laboratory investigations show that the boulders 
are granitic in composition and that some have high potash contents. Most of the original potash feldspar megacrysts have been replaced by muscovite. Carbonate metasomatism has taken place with carbonate apparently derived from the sedimentary matrix replacing parts of the original boulders.

The conditions of deposition of the conglomeratic unit are not known. In some outcrops the boulders form distinct beds, while elsewhere they are scattered through the matrix, which in places is laminated. The boulders are lithologically very similar to major units of pale rock that occur as sheets within parts of the supracrustal belt. Some of these sheets are certainly of intrusive, granitic origin, but others could well be metamorphosed acid volcanic rocks. The presence of recrystallised, coarse-grained, gneissose rocks among the boulders suggests that the Isua supracrustal suite may have been deposited on an older granitic basement.

\section{Relations between the gneisses and the supracrustal rocks}

The outer contact between gneisses and supracrustal rocks was seen at four localities and in all cases was sharp and concordant. Discordant gneiss veins were found to cut the supracrustal rocks near the contact. The inner contact was followed for some distance east of 'Imarssuak' but relations are obscured by deformed pegmatites that follow the contact and cut the rocks on either side of it. These are cut by the basic dykes. The gneisses along this part of the contact of the supracrustal belt are strongly sheared flaser gneisses with blebs of feldspar set in a finer-grained matrix. The boundary between the flaser gneiss and the less deformed gneisses within the dome is gradational. The gneisses away from the contact, both inside and outside the supracrustal belt, contain scattered inclusions of coarse-grained basic, ultrabasic and, in one case, carbonate-rich rocks which could well be derived from the supracrustal rocks.

We interpret the contact between the gneisses and the supracrustal rocks as intrusive, strongly modified by heavy deformation. Nevertheless, we were surprised that so few demonstrable gneiss dykes cut the supracrustals and so few inclusions of supracrustal origin occur within the gneisses.

The same lithological unit in the supracrustal rocks commonly forms the contact rock on both the inner and outer side of the belt, but we could find no evidence to support the idea that the gneisses formed a basement on which the supracrustal rocks were laid down. It is possible that the gneisses are polygenetic, some older than the supracrustals and some, in particular those along the contact, younger.

\section{Structure}

The general bilateral symmetry of the lithological units in the supracrustal belt suggests that it is an isoclinal syncline. The strong shearing along parts of the inner contact, the deformation of the pegmatites that cut this contact and the 
steeply plunging linear fabric element are thought to be related to the diapiric rise of the gneisses in the core of the dome. It is uncertain whether the syncline in the supracrustal rocks is an earlier structure that was refolded by the dome, or whether it is a 'rim syncline', genetically related to the doming and analogous to structures recorded from other greenstone-granite terrains.

\section{Possible economic potential}

The distribution of the various rock types present in the belt strongly resembles that present in many larger greenstone belts in the Canadian and southern African Shields. In particular the presence of a well-developed carbonate-ironstone suite of sediments in the central part of the supposed syncline has a close enough similarity to the gold-bearing upper parts of the Abitibi greenstone sequences (Ridler, 1970) to suggest that a geochemical programme to look for a gold anomaly would be worth while.

\section{Nature of the gneisses}

The gneisses both inside and outside the surpracrustal belt are lithologically identical. Where they are least deformed, the gneisses are seen to be polyphase rocks, lithologically very similar to many of the less deformed Nûk gneisses in the Godthåbsfjord region. The Nûk gneisses are considered to be formed from syntectonic granites (Bridgwater \& McGregor, this report), and it seems likely that the gneisses at Isua have a similar origin. Where the basic dykes become broken up south of the supracrustal belt, the gneisses they cut are similar to many of the type Amitsoq gneisses in the area south-west of Godthåb. There can be little doubt that the gneisses in the Isua area are Amitsoq gneisses that have escaped reworking after the intrusion of the Ameralik dykes.

The Amîtsoq gneisses near Godthåb contain many rafts of basic, ultrabasic and other lithologies (McGregor \& Bridgwater, 1973). It seems likely that many of these rafts are derived from supracrustal rocks equivalent to those of Isua. Lithologies for which a supracrustal origin now seems likely include the layered amphibolites, the garnet-mica-graphite bearing gneisses and some of the finely laminated quartz-magnetite rocks. Other lithologies found as inclusions in the Amîtsoq gneisses cannot be matched with lithologies found at Isua, and some of these, e.g. hornblende-plagioclase-biotite rocks that appear to be derived from gabbros and diorite, are almost certainly not of supracrustal origin.

\section{References}

Keto, L. 1969: Järnmalmfyndigheten vid Isua Väst-Grönland. Program og resuméer af foredrag, IX Nordiske Geologiske vintermøde Lyngby, 5-7 Januar 1970, p. 28 only.

McGregor, V. R. \& Bridgwater, D. 1973: Field mapping of the Precambrian basement in the 
Godthåbsfjord district, southern West Greenland. |Rapp. Grønlands geol. Unders. 55, 2932.

Moorbath, S., O'Nions, R. K., Pankhurst, R. J., Gale, N. H. \& McGregor, V. R. 1972: Further rubidium-strontium age determinations of the very early Precambrian rocks of the Godthaab district, West Greenland. Nature phys. Sci. 240, 78-82.

Moorbath, S., O'Nions, R. K. \& Pankhurst, R. J. 1973: An early Archaean age for the Isua iron-formation. Nature phys. Sci. 245, 138-139.

Ridler, R. H. 1970: Relationship of mineralization to volcanic stratigraphy in the KirklandLardar lakes area, Ontario. Proc. Geol. Ass. Can. 21, 33-42.

V.R.M., Atangmik, 3912 Sukkertoppen, Greenland.

\title{
MAPPING OF THE PRECAMBRIAN BASEMENT IN THE BUKSEFJORDEN REGION, SOUTHERN WEST GREENLAND
}

\author{
Brian Chadwick, Kenneth Coe, Alan D. Gibbs, Martin R. Sharpe \\ and Peter R. A. Wells
}

The summer of 1973 , the second of a six-year series of field studies by teams from the University of Exeter, saw the completion of 1:20000 mapping of the coast region from Ameralik (Narssaq-Præstefjord) south to Sermilik, i.e. approximately between latitudes $64^{\circ} \mathrm{N}$ to $63^{\circ} 30^{\prime} \mathrm{N}$. The area mapped in detail, which excludes the Qilángârssuit island complex, extends inland for about $10 \mathrm{~km}$. A. D. G. Mapped the ground between Ameralik and Buksefjorden, M. R. S. mapped from south of Buksefjorden to, and including, the Tre Brødre anorthosite complex, B.C. covered most of the ground between Tre Brødre and Amitsuarssugssuaq, including Sanerâta timâ, and P. R. A.W. began work in the area between Alángordlia and Sermilik. B. C. also spent a week at the end of the season making a reconnaissance of Qilángârssuit.

The field work was again supported by the GGU cutter $N$. V. Ussing and we gratefully acknowledge the contribution made by skipper Flemming Nielsen to the success of the summer's work. We are also grateful to Feiko Kalsbeek for arranging helicopter support from the Midgård base.

Previous work in the region has already been outlined by Chadwick \& Coe (1973) and we wish to repeat that the terminology set up by McGregor (1973) in the Godthåbsfjord region has been applied with somereservation, particularly with regard to the Nûk gneiss, which we can now show to have been derived by in- 